\title{
FORMULASI MINUMAN FUNGSIONAL TERHADAP AKTIVITAS ANTIOKSIDAN
}

\author{
A.A.A Sauca Sunia Widyantari \\ Program Studi Biologi, Fakultas Teknologi Informasi dan Sains \\ Universitas Hindu Indonesia \\ Email :sochaua12@gmail.com
}

\begin{abstract}
Abstrak
Minuman fungsional merupakan salah satu pangan fungsional. Sebagai pangan fungsional minuman fungsional tentunya harus memenuhi dua fungsi utama yaitu memberikan asupan gizi serta pemuasan sensori seperti rasa yang enak dan tekstur yang baik. Proses pengolahan tanaman herbal menjadi minuman fungsional memerlukan pengetahuan tentang kandungan senyawa aktif dan teknik formulasi. Formulasi atau campuran pada minuman fungsional menjadi bagian terpenting dari minuman fungsional agar cita rasa yang dihasilkan dapat diterima masyarakat dan fungsinya bagi kesehatan dapat dipertanggungjawabkan. Uji organoleptik dilakukan untuk mengetahui tingkat keseukaan atau kelayakan suatu produk agar dapat diterima oleh panelis (konsumen).Kandungan senyawa aktif pada bahan minuman fungsional dapat meningkatkan aktivitas senyawa antioksidan yang dapat meningkatkan sistem kekebalan tubuh.
\end{abstract}

Kata kunci :minuman fungsional, formulasi, antioksidan, sistem kekebalan tubuh.

\begin{abstract}
Functional drinks are one of the functional foods. As a functional food, functional drinks certainly must fulfill two main functions, namely providing nutritional intake and sensory gratification such as good taste and good texture. The process of processing herbal plants into functional drinks requires knowledge of the content of active compounds and formulation techniques. Formulations or mixtures on functional drinks become the most important part of functional drinks so that the resulting flavors can be accepted by the public and their functions for health can be accounted for. Organoleptic test is conducted to determine the level of likeness or feasibility of a product to be accepted by panelists (consumers). The content of active compounds in functional beverage ingredients can increase the activity of antioxidant compounds that can enhance the immune system.
\end{abstract}

Keywords: functional drinks, formulations, antioxidants, immune system. 


\section{PENDAHULUAN}

Indonesia termasuk salah satu Negara yang terinfeksi virus corona (covid-19). segala upaya telah dilakukan oleh pemerintah guna memerangi pandemi ini. Awal terjadi pandemi ini pemerintah mewajibkan tiap warga negaranya untuk rajin mencuci tangan, memakai masker dan belajar, beribadah serta bekerja dari rumah guna membatasi penyebaran virus ini. Namun akhir-akhir ini pemerintah mengeluarkan kebijakkan yaitu pembatasan sosial berskala besar (PSBB) karena dilihat penyebarannya mengalami peningkatan yang sangat signifikan. Selain PSBB pemerintah juga menyarankan agar tetap menjaga sistem kekebalan tubuh.

Menjaga sistem kekebalan tubuh dapat dapat membantu tubuh untuk mencegah dan menghambat benda asing yang masuk dalam tubuh salah satunya adalah virus. Sistem kekebalan tubuh dapat berkurang dalam tubuh. Untuk itu dibutuhkan asupan dari luar yaitu dengan mengkonsumsi minuman atau makanan yang benutrisi. Asupan yang mengandung antioksidan yang tinggi. Antioksidan merupakan senyawa yang dapat membantu meningkatkan system kekebalan tubuhdengan cara mengikat molekul yang sangat reaktif (Winarsi, 2007). Seperti diketahui virus ini sangat bersifat reaktif.

Antioksidan berdasarkan sumbernya dapat dibedakan menjadi 2 yaitu, Antioksidan sintetik adalah antioksidan yang telah diproduksi secara sintetis atau diolah menggunakan bahanbahan kimia, untuk tujuan komersial dan antioksidan alami adalah antioksidan yang diperoleh dari bahan alam, merupakan hasil dari metabolit sekunder tumbuhan yang menghasilkan senyawa aktif seperti senyawa golongan flavonoid.Sumber antioksidan alami dapat diperoleh tidak hanya pada makanan tetapi juga pada minuman yang telah diolah yaitu berupa minuman fungsional dengan formulasi tertentu.

Minuman fungsional merupakan salah satu jenis pangan fungsional. Sebagai pangan fungsional, minuman fungsional tentunya harus memenuhi dua fungsi utama yaitu memberikan asupan gizi serta pemuasan sensori seperti rasa yang enak dan tekstur yang baik. Minuman fungsional dilengkapi dengan fungsi tersier seperti probiotik, menambah asupan vitamin dan mineral tertentu, meningkatkan stamina tubuh dan mengurangi resiko penyakit tertentu (Novita $\mathrm{dkk}$, 2012). Konsep pangan fungsional ada 3 yaitu, 1. Fungsi primer : pangan dilihat dari aspek nutrisional (gizi tinggi), 2. Fungsi sekunder : sifat sensori (penampilan menarik serta cita rasa yang enak) dan 3. Fungsi tersier : pangan bersifat pada aspek fisiologikal (pengaruh positif bagi kesehatan tubuh). Minuman fungsional saat ini telah banyak dikembangkan dengan menggunakan bahanbahan alami seperti daun teh dan bahan-bahan alami seperti rempah-rempah yang dikenal dengan bahan herbal. Bahan-bahan herbal adalah sebutan untuk ramuan bunga, daun, biji, akar atau buah kering untuk membuat minuman yang disebut juga dengan teh herbal (Herviana dkk, 2019). Dan cara penyajian minuman ini pun cukup mudah yaitu dengan cara direbus ataupun diseduh.

Proses pengolahan tanaman herbal menjadi minuman fungsional memerlukan pengetahuan tentang kandungan senyawa aktif dan teknik formulasi. Formulasi atau campuran pada minuman fungsional menjadi bagian terpenting dari minuman fungsional agar cita rasa yang dihasilkan dapat diterima masyarakat dan fungsinya bagi kesehatan dapat dipertanggungjawabkan.Maka sangatlah penting untuk diketahui formulasi yang benar. Uji yang dapat dilakukan untuk mengetahui kebeneran formulasi ini adalah uji orgnoleptik. Uji oragoleptik dilakukan untuk mengetahui tingkat keseukaan atau kelayakan suatu produk agar dapat diterima oleh panelis (konsumen). Dimana uji ini meliputi rasa, aroma dan warna dengan skala penilian $1-5$ (5=sangat suka, $4=$ suka, $3=$ agak suka, $2=$ tidak suka, $1=$ sangat tidak suka) (Herviana dkk, 2019). Maka dari itu penelitian ini bertujuan untuk mengetahui bahan-bahan herbal serta formulasi yang dapat digunakan untuk mengolah minuman fungsional yang dapat meningkatkan sistem kekebalan tubuh.

\section{Metode Penelitian}

Pendekatan interpretatif atau pendekatan secara kualitatif digunakan dalam penelitian ini 
menerapkan metode pendekatan kepustakaan (Library research). Penelitian kepustakaan adalah penelitian yang menekankan pada pustaka sebagai objek studi, yang dalam penelitian ini dilakukan dengan menelaah gagasan para pakar, jurnal, konsepsi yang telah ada, maupun aturan (rule) yang mengikat objek ilmu beserta profesinya. Penelitian ini dimaksudkan untuk menganalisis sesuatu masalah yang menjadi topik penelitian atau konsepsi tersebut.

\section{HASIL DAN PEMBAHASAN} Bahan-bahan minuman fungsional

Bahan-bahan yang digunakan pada minuman fungsional ini dapat berupa rempah- rempah umum dan mudah dicari seperti jahe, bangle, kayu manis, kencur dan sereh atau berupa daun (salam, sirsak), bunga (rosella), kulit (manggis) yang masih segar maupun yang sudah dikeringkan dari tanaman obat yang mempunyai khasiat untuk kesehatan. Senyawa aktif itu berasal dari metabolit sekunder dari suatu tanaman. Senyawa aktif ini yang nantinya yangakan membantu meningkatkan khasiat dari minuman tersebut. beberapa bahan herbal yang dapat meningkatkan kekebalan tubuh dengan olahan minuman serta menghasilkan aktivitas antioksidan yang tinggi dapat dilihat pada tabel 1 dibawah ini

Tabel 1. Beberapa bahan-bahan yang sering digunakan untuk pengolahan minuman fungsional

\begin{tabular}{|c|c|c|c|c|}
\hline No & Nama Lokal & Nama Latin & Famili & $\begin{array}{l}\text { Bagian yang } \\
\text { digunakan }\end{array}$ \\
\hline 1. & Mahkota Dewa & Phaleria macrocarpa & Thymelaceae & $\begin{array}{l}\text { Kulit dan } \\
\text { buah }\end{array}$ \\
\hline 2. & Kayu manis & Cinnamomum burmanii & Lauraceae & Batang \\
\hline 3. & Kencur & Kamferia galangal L. & Zingiberaceae & Rimpang \\
\hline 4. & Jahe & $\begin{array}{l}\text { Zingiber } \\
\text { Rosc.Var.Rubrum. }\end{array}$ & Zingiberaceae & Rimpang \\
\hline 5. & Rimpang Bangle & Zingiber cassumunar Roxb & Zingiberaceae & Rimpang \\
\hline 6. & sereh & $\begin{array}{l}\text { Cymbopogan nardus L. } \\
\text { Rendle }\end{array}$ & Poacea & Daun \\
\hline 7. & Bunga Rosella & Hibiscus sabdariffa $L$. & Malvaceae & Bunga \\
\hline 8. & Kulit manggis & Garcinia mangostana $L$. & Guttiferae & kulit \\
\hline 9. & Daun Salam & Eugenia polyantha & Myrtaceae & Daun \\
\hline 10. & Daun Sirsak & Annona muricata $L$. & Annonaceae & Daun \\
\hline
\end{tabular}

\section{Manfaat bahan-bahan \\ minuman fungsional}

\section{Mahkota Dewa (Phaleria macrocarpa)}

Buah mahkota dewa tidak boleh dikonsumsi bila belum diolah (Winarto, 2013). Mahkota dewa ( Phaleria macrocarpa) dekenal sebgai salah satu tanaman yang berasal dari papua dan dapat tumbuh di tanah yang gembur pada ketinggian $100-1.200$ mdpl. Tanaman ini biasa ditemukan di pekarangan sebagai tanaman hias atau dikebub-kebun sebagai tanaman peneduh. Tinggi tanaman mahkota dewa mencapai 3 meter, serta memiliki buah yang berwarana merah menyala dengan bentukny bulat, diameter $35 \mathrm{~cm}$ dan permukaan licin beralur. Buah mahkota dewa berwarna hijau dan menjadi merah setelah masak, daging buah berwarna putih, berserat dan berair, adapun bijinya bulat, keras, dan berwarna coklat (Herviana dkk, 2019).

Menurut Harmanto (2003), bahwa buah mahkota dewa mengandung senyawa aktif seperti alkaloid, saponin, flavonoid, polifenol, lignin, tanun, dan minyak atsiri yang tergolong di dalam antioksidan. Sehingga buah mahkota dewa dapat dijadikan sebagai pangan fungsional. 
Efek farmakologis mahkota dewa selain bisa digunakan untuk meningkatkan kekebalan tubuh adalah penyakit jantung dan kanker (Winarto, 2013).

\section{Kayu Manis (Cinnamomum burmanii)}

Kayu Manis (Cinnamomum burmanii) mengandung senyawa aktif flavonoid, saponin, dan alkaloid dan mempunyai efek farmakologi seperti menghambat pembentukan radikal bebas yang berbahaya dan membantu memperlambat komplikasi diabetes (Rusita, 2017). Kandungan senyawa fitokimia inilah yang menjadikan kayu manis berpotensial sebagi antioksidan. Selain sebagai penambah cita rasa dan aroma pada minuman, juga sebgai bahan tambhan pembuatan parfum dan obat-obatan. Penggunaannya biasanya dilakukan dengan cara langsung menambahkannya ke dalam makanan dan minuman, baik dalam bentuk utuh, rajangan atau dalam bentuk yang telah dihaluskan (Sundari, 2001). kayu manis juga mempunyai manfaat kesehatan diantaranya sebagai antihiperglikemi.

\section{Jahe (Zingiber officinale rosc)}

Jahe (Zingiber officinale rosc) merupkan jenis rempah-rempahan yang memiliki kemampuan mempertahankan kualitas pangan. Aktivitas antimikroba jahe terhadap mikroba perusak dan pathogen menunjukkan jahe memiliki kemampuan mengawetkan, sehingga tidak perlu menambahkan bahan pengawet kimia. Menurut Ariviani (1999) dalam Hasyim (2009), jahe memiliki kandungan zat yang diperlukan oleh tubuh, kandungan zat tersebut antara lain minyak atsiri $(0,5-5,6 \%)$, zingiberon. Zingiberin, zingibetol, barneol, kamfer, folandren, sineol, gingerin, vitamin (A, $\mathrm{B}_{1}$ dan $\left.\mathrm{C}\right)$, karbohidrat $(20-60 \%)$ dammar (resin) dan asam-asam organic (malat, okasalat) sehingga jahe juga memiliki kemampuan sebagai antioksidan (Uhl, 2000).

\section{Rimpang Bangle (Zingiber cassumunar Roxb)}

Rimpang Bangle (Zingiber cassumunar Roxb) merupakan jenis tanaman obat yang sering digunakan sebagai obat herbal kerena mengandung senyawa falvonoid. Bangle termasuk jenis remapah-rempah. Tanaman ini sangat mudah ditemukan dan dibudidayakan, sehingga merupakan obat tradisional yang cukup potensial untuk dieksplorasi manfaat yang terkandung di dalamya. Bagian yang dapat digunakan sebagai obat adalah rimpangnya. Tanaman bangle memiliki warna kuning bagian dalam, rasanya pedas dan pahit serta memiliki aroma yang khas. Menurut Daroini (2006), rimpang bangle memiliki kadar air 4,66\%, kadar abu $12,87 \%$, lemak $0,81 \%$, protein $21,06 \%$ dan serat kasar 14,61\%. Efek farmakologis dari rimpang bangle ini adalah mengobati demam, sakit kepala, batuk berdahak, nyeri perut dan sakit kuning (Raharjoyo dan Gunardi, 2009).

\section{Sereh (Cymbopogan nardus L.Rendle)}

Sereh (Cymbopogan nardus L.Rendle) memiliki kandungan fitokimia alkaloid, saponin, tanin, flavanoid, fenol dan steroid yaitu sitral, sitronelol (66-85\%), kamfen, sabinen, limonene, terpenol, sitronelal, borneol, geraniol, farnesol, metal heptenon, ndesialdehida, dipenten, bornilasetat, geranilformat, terpinil, asetat, sitronelil asetat, geranil asetat (Veni dkk, 2018). Sehingga berpotensi sebagai antioksidan alami. Efek farmakologis dari sereh adalah penambah nafsu makan, pengibatan pasca persalinan, penurun panas serta pereda kejang (Herbie, 2015). Selain itu juga sereh menghasilkan minyak atsiri yang dapat menghilangkan bakteri, jamur, bau tak sedap dan digunakan sebagai aroma terapi sehingga bisa menenangkan pikiran agar lebih rileks.

\section{Bunga Rosella (Hibiscus sabdariffa L)}

Bunga Rosella (Hibiscus sabdariffa L) memiliki kandungan vitamin, mineral dan komponen bioaktif seperti asam organik, phytosteron dan polifenol, beberapa diantaranya memiliki aktivitas antioksidan. Kandungan penting yang berperan sebagai antioksidan pada kelopak bunga rosella adalah pigemen antosianin yang termasuk kedalam golongan flavanoid (Dwiyanti dan Hati, 2014). Manfaat farmakologis bunga rosella adalah sebagai minuman penambah konsentrasi, mencegah kanker, membantu melancarkan pencernaa, menjaga keshetan organ hati, membantu 
program diet dan membantu menurunkan tekanan darah.

\section{Kulit Manggis (Garcinia mangostana L.)}

Kulit Manggis (Garcinia mangostana L.) manggis jenis ini bnyak kita jumpai dan sering kita konsumsi. Manggis jenis ini memiliki perbedaan pada ukuran buah yang lebih besar dibanding dengan manggis merah. Memiliki senyawa aktif paling banyak adalah xanthone yang memiliki peran untuk melindungi dari penyakit seperti kanker dan diabetes mellitus dan mempunyai aktivitas antioksidan.

\section{Daun Salam (Eugenia polyantha)}

Daun Salam (Eugenia polyantha) merupakan salah asatu bumbu dapur atau rempah-rempah. Daun salam mengandung saponin, triterpen, flavanoid, tanin dan alkaloid. Sedangkan minyak atsiri dari daun salam seskuiterpen, lakton dan fenol (Palupi dkk, 2015). Aktivitas farmakologi antihipertensi, antidiabetes, antioksidan, antidiare, antiinflamasi, imunimodulator (meningkatkan system imun), antibakteri, antikanker (Muhammad dan Ester, 2015).

\section{Daun Sirsak (Annona muricata L.)}

Daun Sirsak (Annona muricata L.) banyak digunakan sebagai obat herbal untuk mengobati berbagai penyakit : penyakit asma, diabetes mellitus, kanker, antimikroba, antivirus. Kandungan senyawa dalam daun sirsak adalah sterois, flavanoid, kumarin, alkaloid, dan tanin. Senyawa flavanoid berfungsi sebagai antioksidan (Puspita dkk, 2019).

\section{FORMULASI BEBERAPA MINUMAN FUNGSIONAL}

Formulasi merupakan bagian terpenting dari pengolahan minuman fungsional kerena akan menentukan aroma, rasa dan warna dari minuman tersebut sehingga dapat terima untuk dikonsumi. Untuk menentukan ketepatan formulasi tersebut ditentukan oleh hasil uji organoleptik meliputi rasa, aroma , warna dan keterimaan masyarakat untuk dikonsumsi. Berikut beberapa jurnal formulasi minuman fungsional.

\section{Formulasi buah kering mahkota dewa dengan penambahan gula dan madu.}

Pembuatan formulasi ini dilakukan dengan cara mengiris (menggunakan pisau stainless agar tidak terjadi reaksi kimia)denag ketebalan $0,3 \mathrm{~cm}$ buah mahkota dewa kemudian dikeringkan pada suhu $55^{\circ} \mathrm{C}$ selama 37 jam. Pembuatan minuman mahkota dewa ini dilakukan dengan cara pemanasan dan perendaman. Untuk pemanasan formulasi yang digunkan adalah $20 \mathrm{~g}$ irisan buah mahkota dewa dalam 1 liter airselama 10 menit. Untuk perendaman dilkukan dengan merendam $4 \mathrm{~g}$ irisan buah mahkota dewakering dalam $200 \mathrm{ml}$ air panas dalam gelas tertutup. Kemudian baik pemanasan dan perendaman ditambahkan masing-masing $12 \%$ gula merah dan $13 \%$ madu. Aktivitas antioksidan pada perlakuan perendaman lebih baik karean pada perendaman memiliki kemampuan yang optimal untuk menurunkan laju reaksi dan oksidasi pada asam lemak. Formulasi dengan penambahan madu memperoleh aktivitas antioksidan paling tinggi ini disebabkan karena kandungan didalam madu yaitu fenol dan asam sitrat sebagai antioksidan sehingga ditambahkan maka senyawa aktif pada mahkota dewa dan madu bersifat sinergis untuk meningkatkan aktivitas antioksidanya. Untuk mengukur aktivitas antioksidan pada penelitian ini menggunakan metode penghambatan MDA dengan nilai perendaman dan penambahan madu sebesar 67,61\% (Aisyah dan Hidayah, 2009).

\section{Formulasi minuman fungsional kayu manis, secang dan daun stevia.}

Sebelum formulasi ini dilakukan terlebih dahulu dilakukan pengukuran aktivitas antioksidan pada masing-masing bahan diukur dan dilakukan uji oraganoleptik meliputi warna, aroma dan rasa. Di sajikan pada tabel 2 hasil uji bahan terhadap aktivitas antioksidan dan tabel 3 formulasi minuman, aktivitas antioksidan dan uji organoleptik.

Tabel 2. Hasil uji bahan 


\begin{tabular}{lcc}
\hline Bahan & Aktivitas antoksidan (\%) & Gula total (\%) \\
\hline Kayu manis & 14,36 & 1,25 \\
Secang & 60,03 & 0,41 \\
Daun stevia & 89,52 & 5,27 \\
\hline
\end{tabular}

Tabel 3. Formulasi, aktivitas antioksidan dan uji organoleptik

\begin{tabular}{llllllll}
\hline Perlakuan & $\begin{array}{l}\text { Penambhan } \\
\text { Kayu manis }\end{array}$ & $\begin{array}{l}\text { Penambahan } \\
\text { secang }(\%)\end{array}$ & $\begin{array}{l}\text { Penambahan } \\
\text { daun } \\
(\%)\end{array}$ & $\begin{array}{l}\text { Aktivitas } \\
\text { stevia } \\
(\%)\end{array}$ & warna & Aroma & Rasa \\
\hline T0 & 0 & 0,25 & 0,2 & $39,85 \pm 0,85$ & $2,28 \pm 0,61$ & $2,68 \pm 0,74$ & $2,72 \pm 0,79$ \\
T1 & 0,5 & 0,25 & 0,2 & $37,21 \pm 1,61$ & $3,32 \pm 0,85$ & $3,48 \pm 0,65$ & $3,36 \pm 0,81$ \\
T2 & 1,5 & 0,25 & 0,2 & $38,43 \pm 0,88$ & $4,20 \pm 0,87$ & $3,80 \pm 0,96$ & $3,28 \pm 1,06$ \\
T3 & 2,5 & 0,25 & 0,2 & $38,42 \pm 0,10$ & $4,00 \pm 0,87$ & $3,80 \pm 1,11$ & $3,04 \pm 0,84$ \\
\hline
\end{tabular}

Berdasarkan tabel 3 formulasi paling tinggi aktivitas antioksidanya adalah minuman kontrol yaitu 39,85\%. Hal ini disebabkan karena formulasi menggunakan kayu manis dan secang bersifat antagonis dimana senyawa aktif yang dihasilkan kayu secang tidak sinergis. Tetapi tidak menurunkan manfaat dari minuman tersebut secara signifikan. untuk uji organoleptik warna dan aroma paling disukai pada penambahan kayu manis sebanyak 1,5\% sedangkan untuk rasa penambahan kayu manis
0,5 1,5 dan 2,5\% sama-sama disukai (Andriana dan Ninik, 2014).

\section{Formulasi rimpang bangle dengan penambahan kayu manis.}

Formulasi ini dilakukan dengan penambhan rimpang bangle, kayu manis dibuat dalam bentuk bubuk instan. Untuk melihat aktivitas antioksidan dan uji organoleptik akan disajikan dalam bentuk tabel

Tabel 4. Aktivitas formulasi minuman rimpang bangle

\begin{tabular}{lllllll}
\hline Perlakuan & $\begin{array}{l}\text { Penambahan } \\
\text { bangle } \\
(\boldsymbol{\%})\end{array}$ & $\begin{array}{l}\text { Penambahan } \\
\text { kayu manis } \\
(\mathbf{K})(\boldsymbol{\%})\end{array}$ & $\begin{array}{l}\text { Aktivitas } \\
\text { antioksidan } \\
\left(\mathbf{I C} \mathbf{5}_{\mathbf{0}}\right. \\
(\boldsymbol{\mu g} / \mathbf{m L}))\end{array}$ & Warna & Aroma & Rasa \\
\hline BK1 & 90 & 10 & 129,38 & 2,95 & 2,39 & 2,31 \\
BK2 & 80 & 20 & 125,31 & 2,76 & 2,54 & 2,52 \\
BK3 & 70 & 30 & 99,91 & 2,40 & 3,09 & 2,82 \\
BK4 & 60 & 40 & 97,89 & 1,96 & 3,56 & 3,54 \\
\hline
\end{tabular}

Berdasarkan tabel 4 diatas penambahan seiring dengan penambahan serbuk kayu manis tingkat aktivitas antioksidan tinggi dengan perbandingan bangle : kayu manis adalah 60:40 yaitu 97,89. Pada aktivitas antioksidan menggunakan $\quad \mathrm{IC}_{50} \quad$ (Inhibition concentration)dimana kalau nilainya kurang dari $50 \mu \mathrm{g} / \mathrm{mL}$ (sangat kuat), IC $\mathrm{I}_{50}$ sampai $100 \mu \mathrm{g} / \mathrm{mL}$ ( kuat), IC $\mathrm{I}_{50} 100$ sampai $150 \mu \mathrm{g} / \mathrm{mL}$ (sedang) dan $\mathrm{IC}_{50} 151$ sampai $200 \mu \mathrm{g} / \mathrm{mL}$ (lemah). Uji organoleptik untuk warna paling disukai yaitu penambhan 90: 10 untuk aroma dan rasa 60:40 karena aroma menjadi manis seiring dengan bertambahnya kayu manis (Zulhamdi dkk, 2018). 


\section{Formulasi minuman fungsional daun sirsak dan penambhan serbuk jahe.}

Formulasi daun sirsak dan jahe dalam bentuk bubuk menunjukkan aktivitas antioksidan serta uji organoleptik yang kuat. Karena senyawa aktif dari daun salam dan jahe bersifat sinergis. Seperti terlihat pada tabel 5 .

Tabel 5. Formulasi, aktivitas antioksidan dan uji organoleptik minuman daun salam dan bubuk jahe.

\begin{tabular}{lllllll}
\hline Perlakuan & $\begin{array}{l}\text { Penambahan } \\
\text { daun } \\
\text { (g) }\end{array}$ & $\begin{array}{l}\text { Penambahan } \\
\text { serbuk jahe } \\
(\boldsymbol{\%})\end{array}$ & $\begin{array}{l}\text { Aktivitas } \\
\text { antioksidan } \\
(\boldsymbol{\mu g} / \mathbf{m L})\end{array}$ & Warna & Aroma & Rasa \\
\hline J0 & 2 & 0 & 128,19 & $4,37 \pm 0,67$ & $3,10 \pm 0,96$ & $2,47 \pm 0,68$ \\
\hline J1 & 2 & 10 & 97,71 & $3,40 \pm 0,56$ & $3,10 \pm 0,54$ & $3,07 \pm 0,69$ \\
J2 & 2 & 15 & 91,15 & $3,57 \pm 0,57$ & $3,30 \pm 0,71$ & $3,17 \pm 0,70$ \\
\hline J3 & 2 & 20 & 84,42 & $3,64 \pm 0,62$ & $3,37 \pm 0,77$ & $3,44 \pm 0,77$ \\
J4 & 2 & 25 & 80,67 & $3,50 \pm 0,69$ & $3,87 \pm 0,63$ & $4,04 \pm 0,67$ \\
\hline
\end{tabular}

Berdasarkan tabel 5 diatas menunjukkan dengan bertambahnya serbuk jahe aktivitas dan uji organoleptik menunjukkan hasil yang baik (puspita dkk, 2019).

\section{Formulasi minuman ektrak rosella dan kulit manggis dan madu}

Formulasi dan uji organoleptik serta aktivitas antioksidan terhadap minuman ekstrak rosella dan kulit manggis dapat dilihat pada tabel 7.

Tabel 7. Formulasi minuman serta uji organoleptik

\begin{tabular}{lllllll}
\hline Perlakuan & $\begin{array}{l}\text { Penambahan } \\
\text { ektrak } \\
\text { rosella (\%) }\end{array}$ & $\begin{array}{l}\text { Penambahan } \\
\text { ektrak kulit } \\
\text { manggis (\%) }\end{array}$ & $\begin{array}{l}\text { Penambahan } \\
\text { madu (\%) }\end{array}$ & Warna & Aroma & Rasa \\
\hline A1 & 40 & 50 & 10 & 2,61 & 4,94 & 2,01 \\
A2 & 50 & 35 & 15 & 2,68 & 5,14 & 6,32 \\
A3 & 40 & 40 & 20 & 3,57 & 5,68 & 6,76 \\
\hline
\end{tabular}

Berdasarkan tabel diatas formulasi yang terpilih untuk uji organoleptik dan aktivitas antioksidan adalah formulasi A3 dimana jumlah $40: 40: 20$. Hal ini disebakan karena senyawa aktif pada rosella dan kulit manggis serta penambhan madu bersifat sinergis sehingga semankin ditambahkan bahan maka aktivitas antioksidan semakin bertambah. Pada uji organoleptik aroma pada A3 disebabkan karena karbohidrat pada madu mempunyai potensi untuk menigkatkan aroma yang diinginkan. Begitu juga dengan rasa pada formulasi A3 lebih dsukai karena penambahan madu yang lebih banyak (Aditya dkk, 2018).

\section{SIMPULAN}

Berdasarkan uraian diatas dapat disimpulkan bahwa proses pengolahan minuman fungsionalsangat bergantung dari formulasi dan senyawa aktif yang ada di dalam bahan tersebut. Pemilihan bahanbaku perlu diperhatikan sehingga bisa bersinergi dan bisa meningkatkan kualitas dan khasiatnya.Uji organoleptik merupakan uji yang digunakan untuk mengontrol formulasi pada minuman tersebut. kebanyakan aktivitas antioksidan pada minuman fungsional sangat baik.Untuk meningkatkan sistem kekebalan tubuh mengonkumsi minuman tradisional bisa menjadi alternatif. Bahannya pun mudah di cara dengan harga yang terjangkau. 


\section{DAFTAR PUSTAKA}

Aditya, D. A., Lia, A dan Tiana Fitrilia. 2018. Formulasi Ekstrak Rosella dan Kulit Manggis Sebagai Minuman Fungsional Yang Kaya Antioksidan. Jurnal Agroindustri Halal. Vol 4. No 1. Hal 022-029.

Aisyah Tri Septiani dan Hidayah Dwiyanti., 2009. Aktivitas antioksidan minuman fungsional dari irisan buah kering mahkota dewa. Jurnal Agritech. Vol 29. No 1. Hal 1-6.

Andriana Murdi, H dan Ninik Rustanti. 2014. Pengaruh Penambahan Kayu Manis Terhadap Aktivitas Antioksidan dan Kadar Gula Total Minuman Fungsional Secang dan Daun Stevia Sebagai Alternatif Minuman Bagi Penderita Diabetes Melitus Tipe 2.Journal of Nutrition College. Vol. 3. No. 3. Hal 362-369.

Dwiyanti, Gebi dan Hati Nuraeni. 2014. Aktivitas Antioksidan Teh Rosela (Hibiscus sabdarifa) Selam Penyimpanan Suhu Ruang. Seminar : Proseding Seminar Nasional Sains dan Pendidikan Sains. Vol. 5. No. 1. Universita Pendidikan Indonesia. Bandung.

Harmanto, N. 2003. Sehat Deangan Ramuan Tradisonal Mahkota Dewa. Agromedia Pustaka : Jakarta.

Hasyim, N. 2009. Kajian Kerusakan Minyak Pada "Jenang Kudus" Dengan Penambahan Ekatrak Jahe (Zingiber Officinale) Selama Penyimpanan.
Skripsi. Fakultas Pertanian. UNS. Surakarta.

Herviana, A., Husain, S dan Muhammad, W. 2019. Pembuatan Teh Fungsional Bebahan Dasar Mahkota Dewa (Phaleria marrocarpa) Dengan Penambahan Daun Stevia. Jurnal Pendidikan Teknologi Pertanian. Vol. 5. Hal S251-S261.

Palupi, H.T.2015. Pengaruh Konsentrasi Ekstrak Daun Cincau (Cyle barbata L.Miers) dan Suhu Ekstraksi Terhadap Karateristik Mie Basah. Jurnal Teknologi Pangan. Vol. 6. No. 1.

Puspita, N., S., Tamrin., Abdul Rahman, B. 2019. Kajian Pembuatan Minuman Fungsional Dari Daun Sirsak (Annona muricat Linn.) Dengan Penambahan Bubuk Jahe (Zingiber Officinale). Jurnal Sains dan Teknologi Pangan. Vol. 4. Hal. 2086-2095.

Rusita, Y. D. 2017. Terapi Herbal Buah dan Sayuran Untuk 10 Penyakit Berbahaya. Galmas Publisher : Surakarta.

Uhl, S.R. 2000. Handbook Of Species, Seasonings and Flavoring. Technomic Publising Co. Inc. Lancaster-USA

Winarsi, H. 2007. Antioksidan Alami dan Radikal Bebas. Kanisius, Yogyakarta.

Zulhamdi, S., Noviar, H dan Raswen Efendi. 2018. Minuman Instan Dari Rimpang Bangle (Zingiber cassumnar Roxb) Dengan Penambahan Kulit Kayu Manis (Cinnamomum burmanii). Jom Faperta. Vol. 5. No. 2. Hal 1-11. 